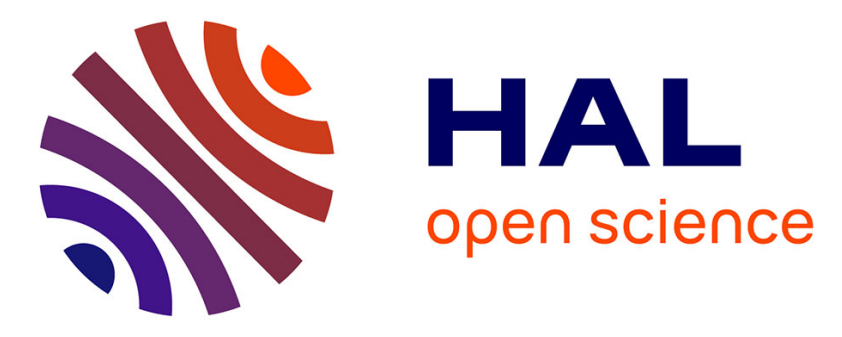

\title{
Converging evidence of underlying competence: comprehension and production in the acquisition of Spanish Subject-Verb agreement.
}

Lisa Hsin, Nayeli Gonzalez-Gomez, Isabelle Barrière, Thierry Nazzi, Geraldine Legendre

\section{- To cite this version:}

Lisa Hsin, Nayeli Gonzalez-Gomez, Isabelle Barrière, Thierry Nazzi, Geraldine Legendre. Converging evidence of underlying competence: comprehension and production in the acquisition of Spanish Subject-Verb agreement.. Journal of Child Language, In press, pp.1-18. 10.1017/S0305000921000301 . hal-03348364

\section{HAL Id: hal-03348364 \\ https://hal.science/hal-03348364}

Submitted on 25 Sep 2021

HAL is a multi-disciplinary open access archive for the deposit and dissemination of scientific research documents, whether they are published or not. The documents may come from teaching and research institutions in France or abroad, or from public or private research centers.
L'archive ouverte pluridisciplinaire HAL, est destinée au dépôt et à la diffusion de documents scientifiques de niveau recherche, publiés ou non, émanant des établissements d'enseignement et de recherche français ou étrangers, des laboratoires publics ou privés. 
Converging Evidence of Underlying Competence: Comprehension and Production in the Acquisition of Spanish Subject-Verb Agreement

Lisa Hsin, Nayeli Gonzalez-Gomez, Isabelle Barrière, Thierry Nazzi, Geraldine Legendre 


\title{
SV COMPREHENSION \& PRODUCTION IN SPANISH
}

\begin{abstract}
A surprising comprehension-production asymmetry in subject-verb (SV) agreement acquisition has been suggested in the literature, and recent research indicates that taskspecific as well as language-specific features may contribute to this apparent asymmetry across languages. The present study investigates when during development children acquiring Mexican Spanish gain competence with $3^{\text {rd }}$ person SV agreement, testing production as well as comprehension in the same children aged between 3.5 and 5.5 years, and whether comprehension of SV agreement is modulated by the sentential position of the verb (i.e., medial vs. final position). Accuracy and sensitivity analyses show that comprehension performance correlates with SV agreement production abilities, and that comprehension of singular and plural third-person forms is not influenced by the sentential position of the agreement morpheme. Issues of the appropriate outcome measure and the role of structural familiarity in the development of abstract representations are discussed.
\end{abstract}




\section{Converging Evidence of Underlying Competence: Comprehension and Production in the Acquisition of Spanish Subject-Verb Agreement}

A recent productive line of research in language acquisition has discovered - and then partially dispelled — a surprising comprehension-production asymmetry (see Clark \& Hecht, 1983), in which children were found to produce $3^{\text {rd }}$ person subject-verb (SV) agreement before they could be shown to comprehend it (e.g., Johnson, de Villiers, \& Seymour, 2005; Pérez-Leroux, 2005). The latest studies, however, indicate an ever-narrowing period between the evident development of these production and comprehension abilities (e.g., in French, Barrière, Goyet, Kresh, Legendre, \& Nazzi, 2016; in Spanish, Gonzalez-Gomez, Hsin, Barrière, Nazzi, \& Legendre, 2017). The inconsistent pattern of results in this literature and the corresponding lack of an overarching account of an asymmetry or its absence is perhaps unsurprising, given that the studies are often limited in modality and in linguistic structure. With respect to modality, the inferences drawn from this line of research tend to contrast novel comprehension results with previously attested production abilities, with the latter typically reflecting spontaneous speech sampled from a comparable population (as in all the above-cited research). With respect to linguistic structure, SV agreement acquisition studies usually restrict the presented stimuli to canonical word-orders, so that claims about the generality of the knowledge acquired remain highly circumscribed (but see the variety of structures tested in French, including in Barrière et al., 2016; Culbertson, Koulaguina, Gonzalez-Gomez, Legendre, \& Nazzi, 2016; Legendre, Barrière, Goyet, \& Nazzi, 2010; Legendre et al., 2014; Nazzi, Barrière, Goyet, Kresh, \& Legendre, 2011). The current study addresses these two existing limitations. We explore the reported SV agreement comprehension/production asymmetry during first-language acquisition by collecting comprehension and production data in a single sample of participants, namely Mexican- 


\section{SV COMPREHENSION \& PRODUCTION IN SPANISH}

Spanish-speaking monolingual preschoolers, and test their comprehension of declarative sentences displaying two word orders, both acceptable in the presented context but of differing frequency in child-directed speech.

\section{Cross-linguistic acquisition of SV agreement: Linguistic and methodological issues}

For virtually all of the languages in which the acquisition of SV agreement comprehension has been studied, comparisons with available production data have suggested that children reliably produce $3^{\text {rd }}$ person SV agreement at an earlier age than the corresponding comprehension abilities emerge. For example, in English, children reliably produce $3^{\text {rd }}$-person SV agreement between ages 2;6 and 3;10 (Brown, 1973), but they have not been found to comprehend it reliably until age 4;0-6;0 (Johnson et al., 2005; Legendre, Culbertson, Zaroukian, Hsin, Barrière, \& Nazzi, 2014). Likewise, in Spanish, children tend to

produce error-free $3^{\text {rd }}$-person SV agreement around age 1;6-1;7 (Montrul, 2004), but reliable comprehension has not been found earlier than age 3;5 (Gonzalez-Gomez et al., 2017; PérezLeroux, 2005). German (Brandt-Kobele \& Höhle, 2010) and Xhosa (de Villiers \& Gxilishe, 2008; Gxilishe, Smouse, Xhalisa, \& De Villiers, 2009) also display this asymmetry. Data from children acquiring French do disrupt this pattern somewhat (Barrière et al., 2016; Culbertson et al., 2016; Legendre et al., 2010; Legendre, Culbertson, Barrière, Nazzi and Goyet, 2010; Legendre et al., 2014; Nazzi et al., 2011). In particular, French-speaking children display successful prefixal, subject clitic-based number agreement comprehension (see below for further discussion of this agreement subsystem) in pointing and preferential looking tasks by 30 months of age (Legendre et al., 2014; Barrière et al., 2016) while they show sensitivity to these agreement markers in head-turn preference tasks as early as 14 months (Culbertson et al., 2016), and spontaneously produce them as early as 24 months (Thordardottir, 2005). 


\section{SV COMPREHENSION \& PRODUCTION IN SPANISH}

However, the kind of production data with which these comprehension findings are ordinarily compared can be subjected to some criticism. Typically, those are spontaneous production data rather than elicited productions (e.g., Brown, 1973; Montrul, 2004). This is potentially problematic because the patterns found in children's spontaneous productions suggest that young children especially tend to be 'grammatically conservative' (that is, their most frequent utterances reflect constructions that they regularly hear in their linguistic environment - and not innovative utterances that may be the output of a grammatical pattern they are still in the process of learning; Snyder, 2011). Indeed, the few exceptions to the reliance of research in this domain on spontaneous production are found in the context of cross-dialectal studies of English (e.g. Barrière et al., 2019; Miller, 2012), and they have led to contradictory results: either disparity (Miller, 2012) or a close relation (Barrière et al., 2019) between comprehension and production of $3^{\text {rd }}$ person singular and plural subject-verb agreement markers. Highlighting the importance of the methodology used to extract SV agreement production in young children, an elicited production study of preverbal subject clitics construed as agreement markers (Jakubowicz \& Rigaut, 2000) reveals that children age 2;0-2;7 answer in a picture-elicitation task questions like 'What is X doing?' with a subject clitic $86 \%-92.4 \%$ percent of the time (depending on their MLU score), compared to a lower spontaneous level of production in an open play session with an experimenter and a parent (45.5\%-71\%). This somewhat muddled collection of findings indicates that drawing inferences about children's underlying competence from spontaneous productions alone may misconstrue the sophistication of their grammatical representations, leading some researchers to draw conclusions of a competence-driven asymmetry that could instead reflect nothing more than differences in experimental conditions.

Another feature of the majority of existing studies on the acquisition of $3^{\text {rd }}$ person SV agreement is the restricted nature of word orders (or constructions) presented as stimuli for 


\section{SV COMPREHENSION \& PRODUCTION IN SPANISH}

comprehension - a design decision that is not without consequences for the conclusions that can be drawn from experimental research. To our knowledge, most studies of SV agreement comprehension in first-language acquisition have used stimuli embodying those languages' basic word orders. In these languages, the SV agreement marker surfaces in a sentencemedial position (e.g., in English, "he sit-S here," or German, "Sie fütter-T einen Hund," she is feeding the dog). Sentence-medial positions are associated with processing disadvantages (e.g., Sundara, Demuth, \& Kuhl, 2011), which may be partially responsible for depressing comprehension accuracy. A contrasting familiarity-based hypothesis, however, would argue for the advantageousness of presenting SV agreement markers for comprehension in their basic word order constructions (or 'canonical positions'): familiarity with the syntactic structure of a stimulus could plausibly facilitate its accurate interpretation (see, e.g., Ambridge, Kidd, Rowland, \& Theakston, 2015). Both Johnson and colleagues (2005) and Barrière and colleagues (2019) found that the sentence-medial marker was comprehended more reliably than the sentence-final one.

The only tested language not following the sentence-medial SV agreement marker pattern is colloquial spoken French, which has been argued to have sentence-initial SV agreement as a consequence of the syntactic reanalysis of preverbal subject pronouns (clitics) into number agreement markers (Legendre et al., 2010). Interestingly, French-learning children as a group have been shown to acquire subject-verb agreement earlier than their cross-linguistic peers (Legendre et al., 2014). There is also a minimal disparity between the age at which French-learning children have been found to comprehend SV agreement (and not only in this salient position, but more generally: see Barrière et al., 2016; Culbertson et al., 2016; Koulagina, Legendre, Barrière, \& Nazzi, 2019) and to produce it reliably (Thordardottir, 2005). However, these studies and others (e.g., Bassano, 2000; Rasetti, 2003) are grounded in spontaneous production data, or else they are measured via parental 


\section{SV COMPREHENSION \& PRODUCTION IN SPANISH}

questionnaire (e.g., using a French version of the CDI, as in Barrière et al., 2016), potentially missing a full measure of the competence possessed by the tested children.

\section{The acquisition of SV agreement in (Mexican) Spanish}

Spanish affords a promising opportunity to explore three hypotheses relating to these observations from the literature: whether comprehension and production truly are acquired asymmetrically in young monolingual learners, whether the representations associated with comprehension performance are more general than mere reflections of children's linguistic input, and the extent to which comprehension reflects lexical knowledge (that would predict similar performance with the same verbs across different word order conditions). Spanish is typically considered to have a default subject-verb-object sentence structure (i.e., it is an SVO language) but also displays a somewhat flexible word order (Gutierrez-Bravo, 2013). It allows location-related prepositional phrases (PPs: e.g., "on the couch," "under the tree") to be placed at the beginning of a sentence regardless of the type of verb used, the status of the subject, etc. (Kempchinsky, 2002; see also Ordónez \& Treviño, 1999). While features concerning the relative importance of information in a sentence can drive PP-fronting in Spanish, they need not (Kempchinsky, 2002), which suggests an adequate degree of functional equivalence between (intransitive) V-PP (e.g., cenan en la cocina "(they) eat in the kitchen") and PP-V (e.g., en la cocina cenan "in the kitchen (they) eat") word orders.

The preverbal (i.e., left-peripheral) position that is available in Spanish-speaking adults' grammar appears to emerge early in the speech of children who are acquiring Spanish as well (Bel, 2005; Villa-García, 2011). To our knowledge, no work has been published on the frequency of preverbal PPs in child-directed Spanish, although our own preliminary corpus analyses of children's language interactions with caregivers suggest they appear extremely infrequently (only $8 \%$ of child-directed utterances containing a PP have the PP preceding the verb; see Villa-García, 2011, for the suggestion of a similar pattern among 


\section{SV COMPREHENSION \& PRODUCTION IN SPANISH}

other fronted constituents). However, Grinstead (2004) shows that fronting of overt subjects and of objects and, crucially, of adverbs - which function similarly to the PPs that we test in this study, both being adjuncts_emerges early in child Spanish (i.e., around age 2-2;6). This suggests that this preverbal position is available to even the youngest speakers for a variety of uses (see also Hsin, 2014; Villa-García, 2011).

\section{The present study}

The present study investigates when during development children acquiring Mexican Spanish gain competence with $3^{\text {rd }}$-person SV agreement-in production as well as comprehension. We assessed comprehension abilities using videos and a pointing task that varied the number reflected in the agreement marker (singular or plural) and the surface position of the agreement marker (sentence-medial or sentence-final). Complementing this comprehension data, we also elicited the production of SV agreement using visual stimuli. Our reporting focuses on the effects of the agreement number (singular vs. plural), as only plural agreement is overtly marked; the age of participants, testing children ranging from 3.5 to 5.5 years of age given previous data showing an emergence of $3^{\text {rd }}$ person SV agreement comprehension in Spanish around 3.5 years of age; and the possibility of a position-related effect on comprehension.

\section{Methods}

\section{Participants}

There were 51 monolingual Mexican Spanish-speaking participants $\left(\mathrm{M}_{\mathrm{age}}=4.56\right.$ years; $\mathrm{SD}=0.62$; range $=3.47-5.63$ years; 28 girls). Each participant completed both position conditions (medial and final) and a production task during a single test administration. All participants who began the experiment completed it.

\section{Materials}

\section{Comprehension task}




\section{SV COMPREHENSION \& PRODUCTION IN SPANISH}

Visual stimuli. Eight pairs of videos of two boys performing a variety of 'intransitive' actions were developed and used in both conditions. The two videos in each pair could only be distinguished by the number of actors engaged in the activity. Either one boy performed the action alone (singular video), or the two boys performed the action jointly together and simultaneously (plural video), both boys appeared in every video (see Fig.1). Videos were 6seconds-long. A video of the boys dancing in a celebratory manner was created to supply implicit feedback on the side of the correct video after each trial (as previously done in Gonzalez-Gomez et al., 2017).
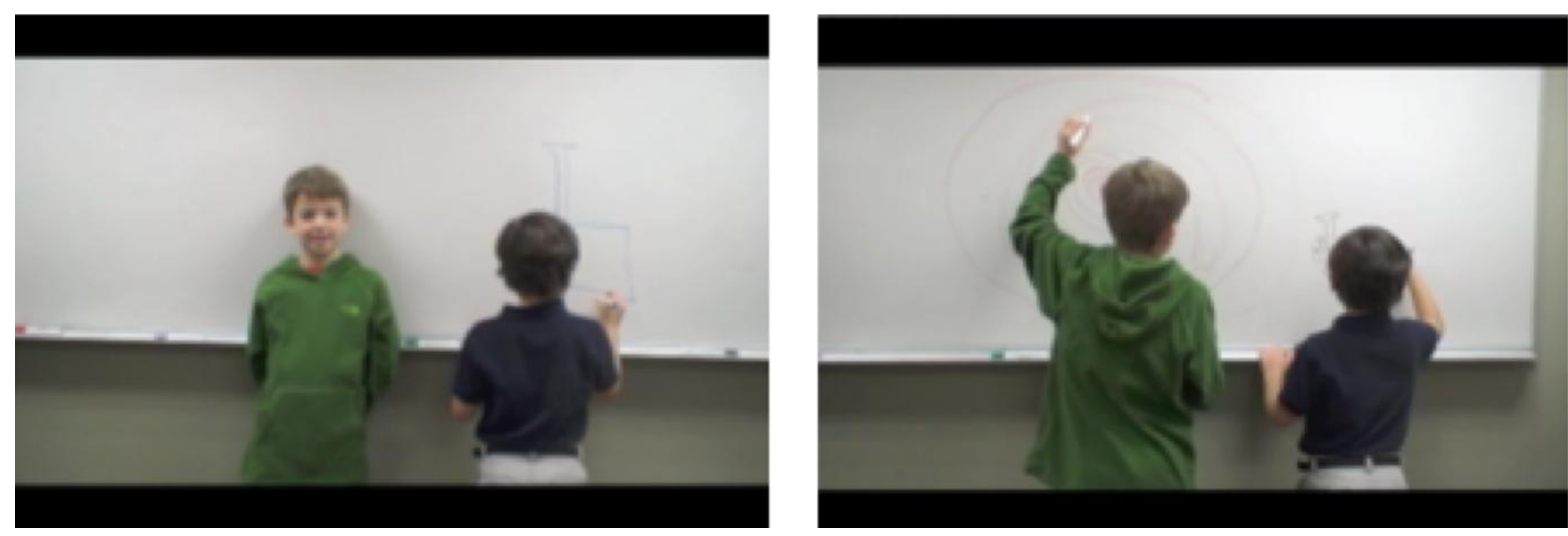

Figure 1. Still image from one video pair (dibujar "draw": left: singular action; right: plural action).

Verbal stimuli. Auditory stimuli consisted of short null subject sentences having either an intransitive verb + prepositional phrase for the sentence-medial condition (e.g., cena en la cocina '(he) dines in the kitchen' vs. cenan en la cocina '(they) dine in the kitchen') or a prepositional phrase + intransitive verb for the sentence-final condition (e.g., en la banca salta 'on the bench (he) jumps' vs. en la banca saltan 'on the bench (they) jump': see Appendix 1). Eight familiar verbs, referring to the eight actions in the videos, were used: escribir "write", saltar "jump", correr "run", comer "eat", llorar "cry”, jugar "play", dibujar "draw", and leer "read". These verbs were chosen because they are known by many children 


\section{SV COMPREHENSION \& PRODUCTION IN SPANISH}

according to the Mexican Spanish adaptation (Jackson-Maldonado, Marchman, Thal, Bates, \& Gutierrez-Clellen, 1993) of the MacArthur CDI "Words and phrases" (Fenson et al., 1993) and can all be used intransitively.

\section{Production task}

A subset of the visual stimuli and procedure of the Diagnostic Evaluation of the Language Variation (DELV; Seymour, Roeper, De Villiers \& De Villiers, 2005) was adapted for the purpose of this study to measure children's subject-verb agreement productions. The DELV stimuli in that section consist of pairs of pictures depicting ethnically diverse children and adults. The left picture systematically depicts two individuals (i.e., animals, children, or adults) instigating an event while the right picture depicts a single individual of the same semantic category performing the same action. We elected to use an adaptation of the DELV rather than a less constrained elicitation task in order to increase our chances of obtaining reliable, analyzable responses.

In the English version, the task is a sentence completion task during which the experimenter first produces a sentence that describes the left plural version of the picture (e.g. the horses eat hay) after they have described different elements of the pictures (e.g. horses, hay, rabbit, carrots) and prompts the child to produce the singular version of the same verb (e.g. but the rabbit...) while pointing at the singular version of the picture depicting a rabbit eating carrots: the elicitation of the $3^{\text {rd }}$ person singular in English is motivated by the fact that this feature varies across different varieties of English (Barrière et al., in press).

We adapted this section to Mexican Spanish so that the $3^{\text {rd }}$ person singular items were elicited for half of the set of stimuli and the $3^{\text {rd }}$ person plural for the other half, given that our purpose was to assess children's ability to produce the singular and the plural $3^{\text {rd }}$ person agreement makers.

\section{Procedure}




\section{SV COMPREHENSION \& PRODUCTION IN SPANISH}

\section{Comprehension task}

Each child was tested individually in a quiet space within their kindergarten. Children sat in front of a 22" LCD touchscreen monitor (Planar PX2230MW). The experimenter sat behind the child and produced each of the stimulus utterances live. Task presentation order was counterbalanced.

In the comprehension task, first, the child was told that she would see images on the screen and be asked to touch some of them. The participant saw four training trials that displayed pairs of familiar objects (e.g., an apple and a house). After 12 seconds of visual presentation, the live experimenter said: viste la casa? muéstrame con tu dedo la casa, dónde está la casa? ("Did you see the house? point where the house is, where is the house?"). When the child touched the image, the monitor's background changed color to indicate that the response had been recorded. After the training trials, the introductory video of the boys appeared, while the experimenter explained that the child would now see videos of them doing different activities and that again the child would be asked to tap one of the videos.

The test phase then began, consisting of eight trials. During each trial, each video was played twice in silence on one of the sides of the screen, followed by the other video. The experimenter then said: viste? cenan en la cocina, muéstrame con tu dedo en cuál imagen cenan en la cocina, dónde cenan en la cocina ('Did you see? Dine-3PL in the kitchen, point where dine-3PL in the kitchen, where dine-3PL in the kitchen?'). The two videos then reappeared simultaneously in their original locations, during which time the child would touch the matching video. The background changed color, and the celebratory video appeared on the side of the correct response (supplying implicit feedback). The side, order of singlevs. dual-actor, and task presentation order were counterbalanced across participants.

\section{Production task}




\section{SV COMPREHENSION \& PRODUCTION IN SPANISH}

The procedure was similar to the standard DELV administration. At the beginning of the testing the experimenter told children: 'Ahora te voy a enseñar unas imágenes y te voy a decir algo sobre cada una. Quiero que mires las imágenes y que termines lo que voy a decir' (I am now going to show you some pictures, and I am going to tell you something about each image. I want you to look at them carefully and to finish what I am going to say). Children were then presented with 10 different items, in each trial elements of the pictures were first described by the experimenter and then participants were expected to complete sentences, for example, 'Veo unas colas cortas y veo una cola larga. El gato tiene cola corta, pero los perros..." (I can see a short tail and I can see a long tail. The cat has a short tail, but the dogs...). The task elicited the production of 5 plural verbs (i.e., tener 'have, dormir 'sleep', lavar 'wash' in the present and two instances of estar 'be' in the past) and 5 singular verbs (i.e., tener 'have', andar 'ride', empujar 'push', nadar 'swim', jugar 'play') in the canonical position (see Appendix 2). The score considers the accurate production of $3^{\text {rd }}$-person singular and plural agreement markers with an overt subject in the context of these sentences.

\section{Results}

\section{Production task}

In the production task participants could produce up to ten correct responses: five singular and five plural. Overall, on average, they produced 8.80 correct responses $(S D=1.45): 4.43$ correct singular utterances $(S D=0.78)$ and 4.37 correct plural utterances $(S D=0.94)$. Both of these values were significantly greater than chance, where chance was defined as 50\% accuracy: for singular items, $t(50)=17.67, p<.001$; for plural items, $t(50)=14.27, p<.001$. All but three participants answered at least two singular items and two plural items correctly. Four types of errors were documented: exchanging singular for plural forms or vice versa, producing a bare present participle (without the inflected auxiliary verb), producing only the subject noun of the target phrase, and failure to supply a response. Sixteen 


\section{SV COMPREHENSION \& PRODUCTION IN SPANISH}

participants produced a singular verb where a plural was needed; 2 participants produced a plural verb where a singular was needed. Nine participants produced a bare present participle. The subject noun alone was produced as a response by 11 of the participants, while 7 participants produced an uninterpretable response. As attested by the high average accuracy on singular and plural items across the sample, however, the incidence of all of these errors was quite low (13.65\% of all trials).

The sample was divided into two age groups by a median split: the younger group's mean age was 4.03 years (range=3.47-4.50), while the older group's mean age was 5.11 years (range=4.50-5.63). A two-way ANOVA was conducted with Number (singular vs. plural) as a within-subjects factor and Age Group (younger vs. older) as a between-subjects factor. There was a significant effect of Age Group, $F[1,49]=8.18, p=.006$, partial $\eta^{2}=0.26$, attesting better accuracy among older participants, which was confirmed via simple correlation analysis using a continuous Age variable, $r(49)=.39, p=.005$. There was no significant effect of Number, $F[1,49]=0.20, p=.66$, partial $\eta^{2}=0.004$, confirming the lack of difference between the two conditions, nor was there a significant interaction, $F[1,49]=0.20$, $p=.66$, partial $\eta^{2}=0.004$

Accuracy was also compared against chance separately for the older and younger groups. Despite the fact that the older group produced accurate responses significantly more often than the younger group, both groups on average performed at above-chance levels in both conditions (all $p s<.001$; see Figure 2). Moreover, accurate responses on singular items were significantly correlated with accurate plural responses, $r(49)=0.43, p=.002$. Therefore, in subsequent analyses, we collapse singular and plural production scores into a single Production Score. 


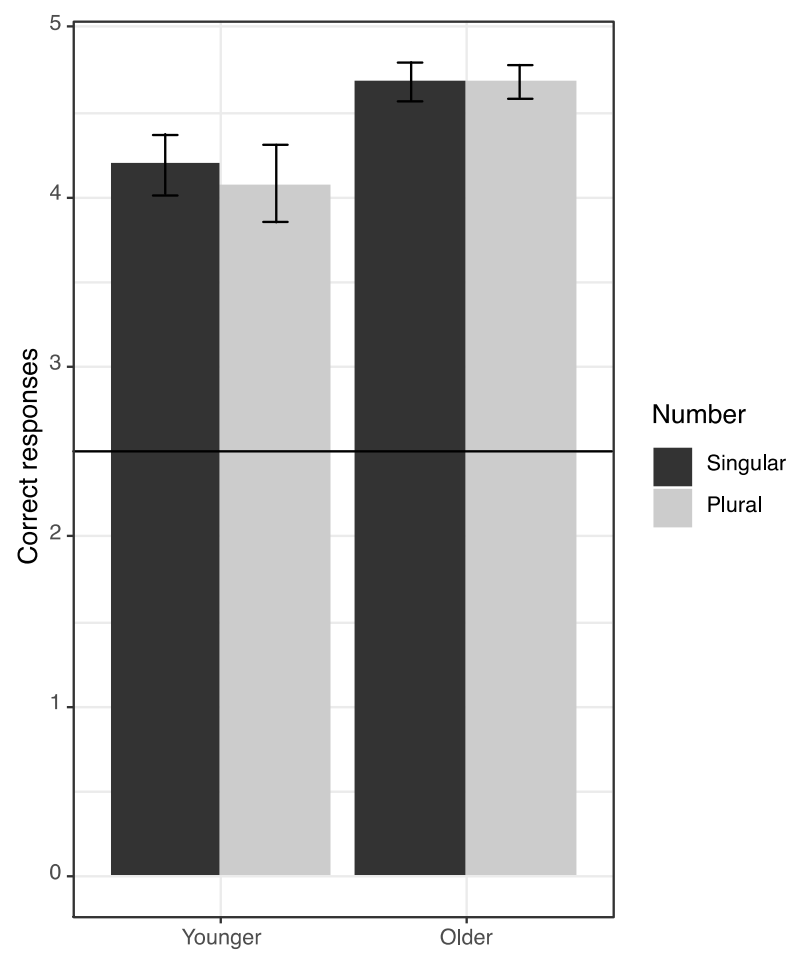

Figure 2. Number of correct production responses in Younger and Older groups, separated by number (Singular vs. Plural).

\section{Comprehension task: Accuracy}

Accuracy results are presented in Figure 3. Overall, participants pointed to the video that corresponded to the verbal stimulus in $68.75 \%$ of trials $(S D=20.03 \%)$, which was significantly different from the $50 \%$ chance level, $t(50)=6.68, p<.001$. A three-way mixeddesign ANOVA was conducted with Number (singular vs. plural) and Position (medial vs. final) as within-subjects factors and Age Group (younger vs. older) as a between-subjects factor (using the same median split as for the Production analysis). There was a significant effect of Number, $F[1,49]=49.08, p<.001$, partial $\eta^{2}=0.65$, attesting better accuracy for plural trials; comparisons to $50 \%$ showed that accuracy was better than chance for plural trials, $M=81.86 \%, t(50)=12.96, p<.001$, but not singular trials, $M=55.64 \%, t(50)=1.38$, $p=0.17$. There was a significant effect of Age Group $\left(F[1,49]=12.76, p=.001\right.$, partial $\eta^{2}=$ 0.46), attesting better accuracy in older children; yet, accuracy was better than $50 \%$ chance 


\section{SV COMPREHENSION \& PRODUCTION IN SPANISH}

for both the older group, $M=77.75 \%, t(24)=8.39, p<.001$, and the younger group, $M=60.10 \%$, $t(25)=2.63, p<.014$. There was no significant effect of Position, $F[1,49]=0.15, p=.699$, partial $\eta^{2}=0.004$, nor any significant interactions.
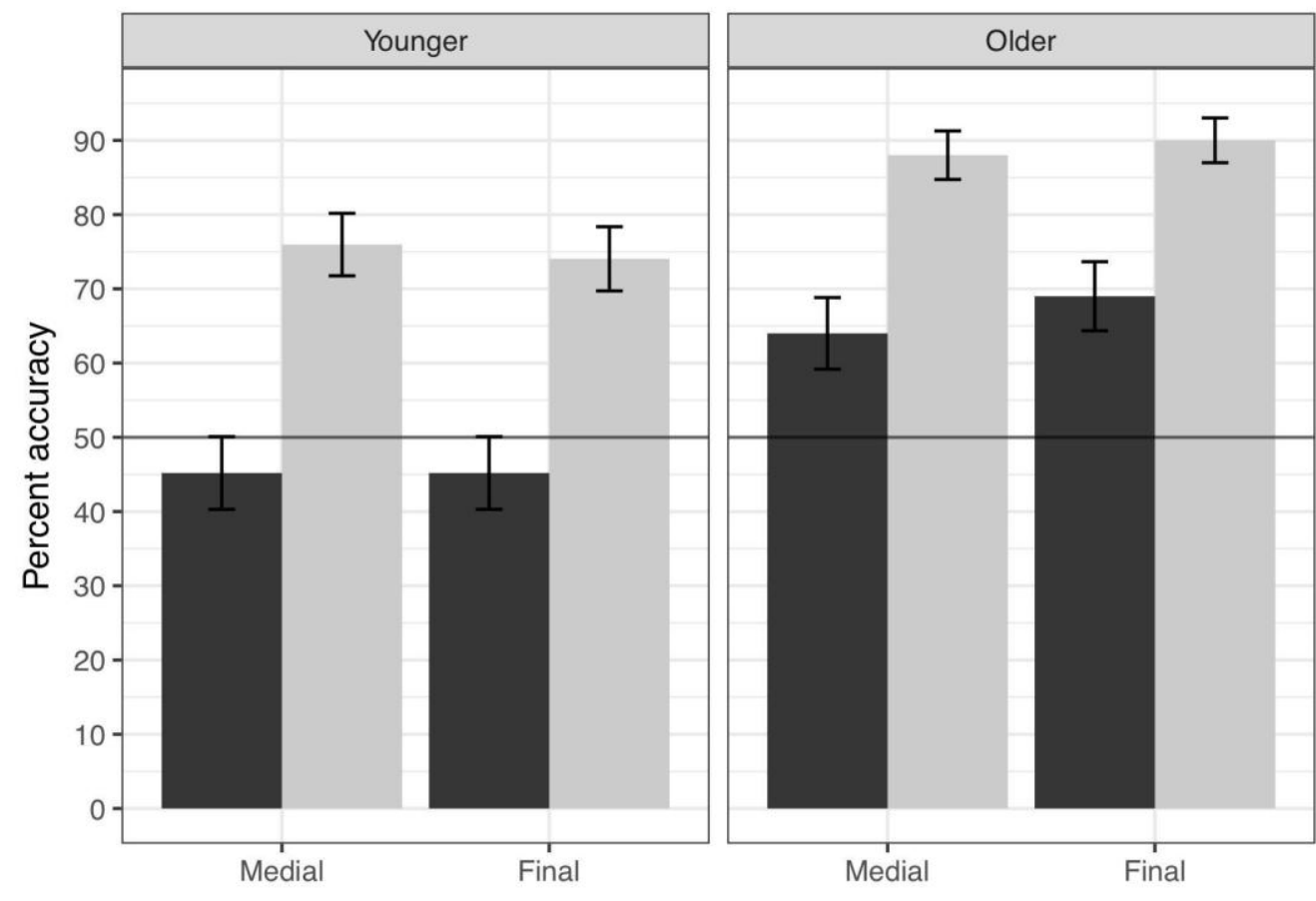

Number

Singular

Plural

Figure 3. Pointing accuracy separated by Number, sentential Position, and Age Group.

We also examined the correlations between comprehension accuracy, production accuracy, and participant age. Overall comprehension accuracy was significantly correlated with production accuracy, $r(49)=.32, p=.017$, and with age, $r(49)=.49, p<.001$. For singular items, comprehension accuracy was marginally correlated with production accuracy, $r(49)=.27, p=.058$, and significantly correlated with participant age, $r(49)=.44, p=.001$. For plural items, comprehension accuracy was significantly correlated with production accuracy, $r(49)=.32, p=.023$, and with participant age, $r(49)=.38, p=.005$.

\section{Comprehension task: Sensitivity}

Sensitivity analyses were developed to reflect the proportion of a child's points to a given video type (singular or plural) that was linked to hearing that verbal stimulus type (see 


\section{SV COMPREHENSION \& PRODUCTION IN SPANISH}

Johnson et al., 2005). For each participant, we computed two proportional sensitivity scores, one for SG trials and one for PL trials, by dividing the hit rate (i.e., the points to the SG video when a SG verbal stimulus was presented) by the sum of the hits and false alarms (i.e., all points to the SG video). In multimodal preference tasks (i.e., where participants are asked to map auditory stimuli to visual ones), participants can sometimes show a preference for one type of visual stimulus regardless of the auditory stimulus that is presented with it. Sensitivity analyses are used to compensate for those preferences: they represent a contingent value based on the number of times a participant's selection of one video or the other can be attributed to the auditory stimulus. That is, whereas an accuracy measure simply computes the proportion of video-selection responses that aligned with the auditory stimulus, the sensitivity measure computes how often the selection of a singular or plural stimulus was correct in light of the overall frequency of the selection of each.

Sensitivity results are presented in Figure 4. Overall, sensitivity scores were 69.55\% $(S D=21.88 \%)$, which was significantly different from the $50 \%$ chance level, $t(50)=6.38$, $p<.001$. A three-way mixed-design ANOVA was conducted with Number (singular vs. plural) and Position (medial vs. final) as within-subjects factors and Age Group (younger vs. older) as a between-subjects factor (using the median split as above). There was a significant effect of Number $\left(F[1,49]=5.83, p=.020\right.$, partial $\left.\eta^{2}=0.11\right)$, attesting better sensitivity for singular; yet, sensitivity was significantly above the 0.5 chance level for both $\mathrm{SG}, M=0.72$, $t(50)=6.29, p<.001$, and PL, $M=0.67, t(50)=6.30, p<.001$, stimuli. There was a significant effect of Age Group, $F[1,49]=13.27, \mathrm{p}<.001$, partial $\eta^{2}=0.64$, attesting better sensitivity in older children; yet, sensitivity was better than the 0.5 chance level for both the older group, $M=0.80, t(24)=8.57, p<.001$, and the younger group, $M=0.60, t(25)=2.31, p=.030$. There was no significant effect of Position, $F[1,49]=0.001$, $\mathrm{p}=.973$, partial $\eta^{2}<0.001$, nor any significant interactions among the factors. 

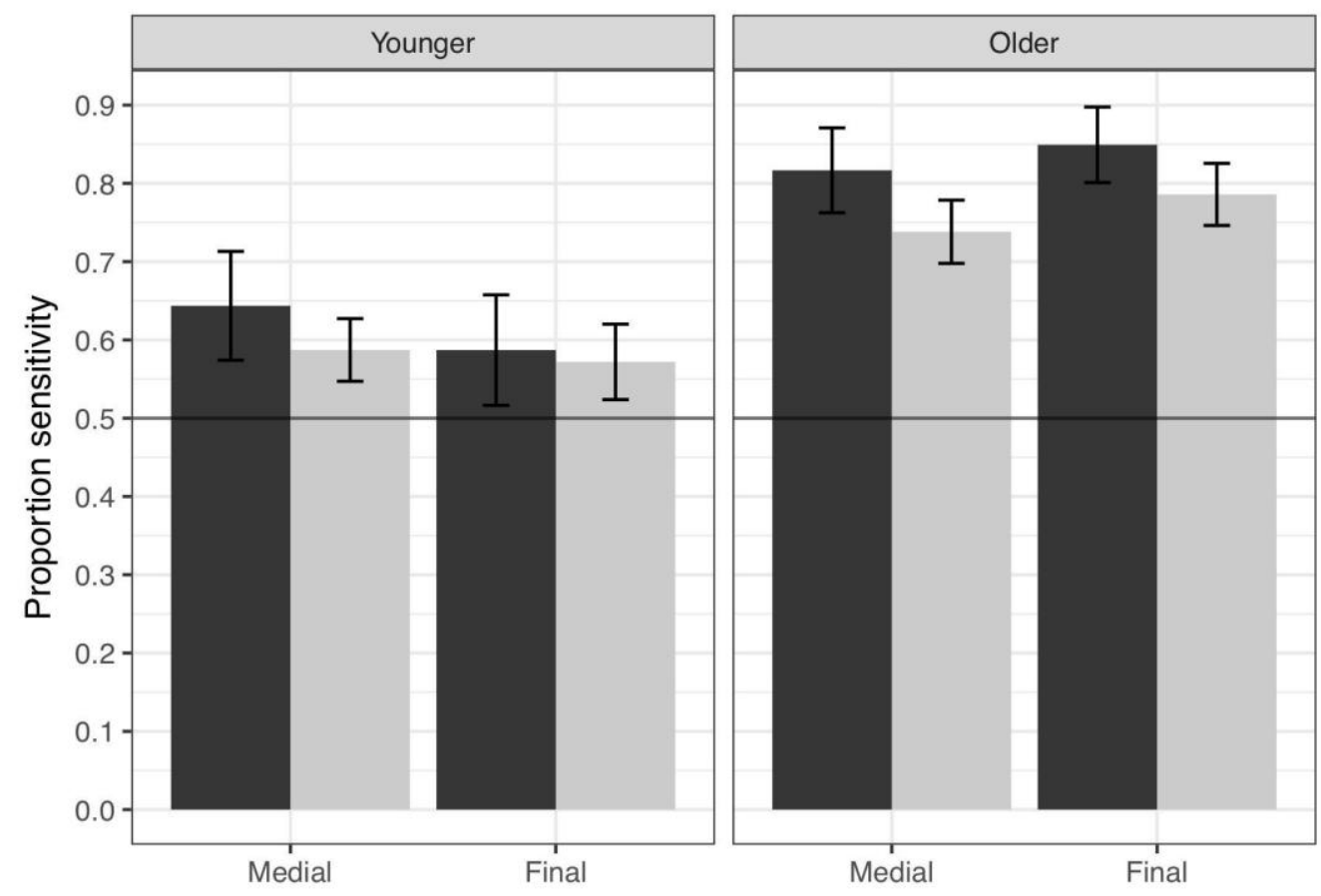

Number

Singular

Plural

Figure 4. Pointing sensitivity separated by Number, sentential Position, and Age Group

As with the accuracy analysis, we examined the correlations between sensitivity in comprehension, production accuracy, and participant age. Overall sensitivity was significantly correlated with production accuracy, $r(49)=.33, p=.018$, and with participant age, $r(49)=.38, p=.005$. For singular items, sensitivity in comprehension was significantly correlated with production accuracy, $r(49)=.33, p=.018$, and with participant age, $r(49)=.42$, $p=.002$. For plural items, sensitivity in comprehension was likewise significantly correlated with production accuracy, $r(49)=.29, p=.038$, and with participant age, $r(49)=.49, p<.001$.

\section{Discussion}

Our results demonstrate that children acquiring Spanish display comprehension of $3^{\text {rd }}$ person SV agreement as early as 3.5 years of age, and that comprehension continues to increase over the 2-year period reflected in the age range of our sample. These results also show that participants' processing of this agreement paradigm is position-independent, children's comprehension being similar in the medial and final position. Furthermore, while 


\section{SV COMPREHENSION \& PRODUCTION IN SPANISH}

accuracy on plural trials was higher than on singular trials, sensitivity to singular stimuli was higher than it was to plural agreement. Sensitivity analyses also revealed that older and younger children both comprehended the agreement marker at above-chance levels. The production results show performance above chance level for the older and younger children, but better accuracy was found for the older children. Critically, comprehension ability of SV agreement, as measured by both accuracy and sensitivity, was correlated with production ability and age.

The comprehension results showed a significant effect of participant age when examining both outcome measures (i.e., accuracy and sensitivity). Nevertheless, this effect was associated with above-chance sensitivity for both the younger and the older children in our sample, indicating that we may not yet have reached the lower age bound at which Spanish-acquiring children can comprehend $3^{\text {rd }}$ person SV agreement (contra Pérez-Leroux, 2005). While sensitivity was above chance in both the older and younger groups, this was not the case with the accuracy measure: younger children displayed chance-level accuracy on singular trials. The disparity is evident in results for the younger children on singular trials, which was dependent on whether accuracy or sensitivity measures were examined, and it underscores the importance of summarizing data in multiple ways in preparation for hypothesis testing. In particular, when there are a priori reasons to believe that chance-level performance could be due to design-related rather than knowledge-related factors— such as the plural bias that has been found in many intermodal comprehension tasks like this one (e.g., Gonzalez-Gomez et al., 2017)—alternative summary measures like the sensitivity calculation can reveal mastery that would otherwise be obscured. In light of the full set of results we uncovered, the present findings represent a narrowing of the gap between the age of development of $3^{\text {rd }}$ person SV comprehension abilities in Spanish-speaking (age 3;5) and French-speaking children (age 2;6), and a widening between Spanish- and English-speaking 


\section{SV COMPREHENSION \& PRODUCTION IN SPANISH}

(age $4 ; 0$ ) children, which our future research will continue to explore by testing younger children in both Spanish and English.

From a methodological standpoint, our findings highlight the question of the kind of outcome measure to use in forced-choice tasks like the ones presented here: accuracy, reflecting the proportion of points to a visual stimulus that match the verbal one, or sensitivity, reflecting the proportion of points to a visual stimulus that are motivated by the verbal one. Given the difficulty in generating equivalently appealing visual stimuli to represent different meanings, a measure like the sensitivity computation serves to minimize the potential of a preference for one of the stimulus types and to focus the analysis on genuine comprehension ability. Indeed, in contrast to the results of our accuracy analyses that suggested greater success on plural than on singular trials, sensitivity scores showed that participants were more sensitive to the singular cue than to the plural one-somewhat surprisingly given that it is the plural that is overtly marked.

The observed greater sensitivity to the singular form, however, might be explained by the relative reliability of the singular and plural markers we tested. In addition to marking the third-person plural, /-n/ also marks second-person plural in Mexican Spanish, and is a frequent final phoneme in (singular) nouns (e.g., buzón 'mailbox', opción 'option') and adjectives (e.g., marrón 'brown', holgazán 'lazy'). It is also frequently found in (singular) deverbal nouns like canción 'song' or decisión 'decision'. In many of these singular/-n/ words, the syllable for which /-n/ is the coda is stressed, lending it additional salience - as a potential cue to morphological singularity. And although the tested singular forms share a final phoneme, either /-a/ or /-e/, that occurs in myriad nouns and adjectives in Spanish, they are associated with singular number in those contexts as well, or, with default (singular) number in verbs. Hence the forms associated with the tested $3^{\text {rd }}$ person singular markers in this study are more reliable than the plural one. 


\section{SV COMPREHENSION \& PRODUCTION IN SPANISH}

The present study also extends recent findings on the generality of SV agreement acquisition by exploring the role of the position of the verb on which the agreement morpheme surfaces within the stimulus utterance. We tested comprehension of the $3^{\text {rd }}$ person agreement marker in two positions, a more canonical and frequent structure, and one that places the marker in a processing-advantageous position. The fact that we found no difference between these conditions suggests that it is not merely familiarity with the complete sentences that participants heard that facilitates comprehension of $3^{\text {rd }}$ person SV agreement; rather, children were also able to attend to the interpretation-relevant cue in the medial position (cf. Barrière et al., 2019, which found that differences in position-dependent agreement interpretation in English were related to the linguistic variant of English that children were acquiring). The similarity of responses across agreement marker positions found in the current study indicates the presence of an abstract representation of SV agreement that can be used to comprehend an utterance whether its surface form reflects the canonical order or not (contrasting with Sundara et al., 2011, studying younger children). Given that the sentence-final structure is minimally familiar to children, it is implausible that they would be able to retrieve identical utterances from their memory and apply those to comprehension here (cf. item-based theories of acquisition; Tomasello, 2003; more specifically Blom, Paradis, \& Sorenson Duncan, 2012, on English $3^{\text {rd }}$ person singular agreement). Instead, they likely developed an abstract representation of 'singularity' and 'plurality' for application whenever the relevant morpheme is encountered, which also provides evidence against a lexically-based account of grammatical development.

These results add to the growing literature on the comprehension of plural-marking morphology (e.g., nominal plurals; Arias-Trejo, Cantrell, Smith, \& Canto, 2014) SV agreement in Spanish first-language acquisition and narrow the developmental disparity between early comprehension and production (age 1;6; Montrul, 2004) of SV agreement in 


\section{SV COMPREHENSION \& PRODUCTION IN SPANISH}

that language (also documented for English in Barrière et al., 2019). While older than Montrul's (2004) participants, the participants in this study performed well above chance in the production of both singular and plural items. The errors that our participants made in production tended to reflect $3^{\text {rd }}$ person SV agreement errors, and specifically the use of the singular form where the plural was needed; the second most frequent error in which a verb form was produced involved children producing the bare present participle. Although both of these errors involve a failure to produce the third-person singular agreement, they could also be instantiations of non-finite root forms (Davidson \& Legendre, 2003; Wexler, 1998): tense is omitted from both (although aspect is indeed represented in the present participle response). These error patterns suggest that while participants overwhelmingly responded with target forms in the production task, their mastery of SV agreement in Spanish is still incomplete, for the purposes of production just as it is for comprehension.

The link between comprehension and production found in our study attests that both manifestations of the acquisition of $3^{\text {rd }}$ person SV agreement go hand in hand, further weakening initial hypotheses that this aspect of morphosyntax represents a special case of a comprehension-production asymmetry/dissociation. The significant correlations between comprehension and production abilities suggest that comprehension and production may indeed develop in tandem in individuals. The data that we have do not allow for directional, causal claims one way or the other, but they do show that a strong asymmetry between production and comprehension abilities is absent, at least in our sample. It is a matter of collecting data in both of these modalities from the same sample of participants, in addition to developing protocols that are of roughly equivalent difficulty in each modality so that, in principle, children's grammatical resources can be equivalently called upon in both. Future research should explore the possibility of collecting multiple measures of comprehension and production in the same sample to further refine theoretical hypotheses. The inclusion of 


\section{SV COMPREHENSION \& PRODUCTION IN SPANISH}

multiple measures in each modality would be especially useful for characterizing production abilities, in light of the possible influence of grammatical conservatism on spontaneous productions and of the potential for reluctance to 'perform' verbally in elicited production tasks in an unfamiliar setting with an unfamiliar experimenter, and so forth.

To conclude, the present study found clear evidence of Mexican 3;6-5;6-year-old children's ability to use both singular and plural third-person agreement morphology to map verbal stimuli to their visual counterparts, independently of the sentential position of the agreement marker. We therefore have yet to identify the lower age limit of $3^{\text {rd }}$ person SV agreement comprehension in Spanish, comprehension that appears to stem from an abstract representation of how verbal agreement relates to meaning. Furthermore, our results indicate that the comprehension and production of subject-verb agreement go hand in hand, suggesting that this aspect of morphosyntax might not represent a special case of a comprehension-production asymmetry/dissociation as previously thought. 


\section{SV COMPREHENSION \& PRODUCTION IN SPANISH}

\section{References}

Ambridge, B., Kidd, E., Rowland, C. F., \& Theakston, A. L. (2015). The ubiquity of frequency effects in first language acquisition. Journal of Child Language, 42(02), 239-273. https://doi.org/10.1017/S030500091400049X

Arias-Trejo, N., Cantrell, L. M., Smith, L. B., \& Canto, E. a. A. (2014). Early comprehension of the Spanish plural. Journal of Child Language, 41(06), 1356-1372. https://doi.org/10.1017/S0305000913000615

Barrière, I., Goyet, L., Kresh, S. Nazzi, T., \& Legendre, G. (2016) Uncovering Productive Morphosyntax in French-learning Toddlers: A Multidimensional Methodology Perspective. Journal of Child Language, 43 (5), 1131-1157. doi:10.1017/S0305000915000495

Barrière, I., Kresh, S., Aharodnik, K., Legendre., G. \& Nazzi, T. (2019) The comprehension of $3^{\text {rd }}$ Person Singular $-s$ by NYC English-speaking Preschoolers. In M. Rispoli \& T. Ionin (eds) Three Streams of Generative Language Acquisition Research. Amsterdam: John Benjamins, Language Acquisition and Language Disorders Series. 7-33.

Barrière, I., Kresh, S., Aharodnik, K., Legendre., G., \& Nazzi, T. (in press) The comprehension of $3^{\text {rd }}$ Person Singular - s by NYC English-speaking Preschoolers. In M. Rispoli (ed.) Proceedings of the Generative Approaches to Language Acquisition North America 7. Amsterdam: John Benjamins.

Bel, A. (2005). Aspectos de la adquisición del orden de palabras: la posición del sujeto en castellano y catalán. RAEL: Revista Electrónica de Lingüística Aplicada, 4, 36-48.

Blom, E., Paradis, J., \& Sorenson Duncan, T. (2012). Effects of input properties, vocabulary size and L1 on the development of third person singular -s in child L2 English. Language Learning, 62, 965-994. https://doi.org/10.1111/j.1467-9922.2012.00715.x 


\section{SV COMPREHENSION \& PRODUCTION IN SPANISH}

Brandt-Kobele, O.-C., \& Höhle, B. (2010). What asymmetries within comprehension reveal about asymmetries between comprehension and production: The case of verb inflection in language acquisition. Lingua, 120(8), 1910-1925. doi:10.1016/j.lingua.2010.02.008

Buerkin-Pontrelli, A., Culbertson, J., Legendre, G., \& Nazzi, T. (2017). Competing models of liaison acquisition: Evidence from corpus and experimental data. Language, 93(1), 189-219. https://doi.org/10.1353/lan.2017.0006

Clark, E. V., \& Hecht, B. F. (1983). Comprehension, production, and language acquisition. Annual Review of Psychology, 34(1), 325-349. doi.org/10.1146/annurev.ps.34.020183.001545

Davidson, L., \& Legendre, G. (2003). Defaults and competition in the acquisition of functional categories in Catalan and French. In R. Núñez-Cedeño, R. Cameron, \& L. López (Eds.), Romance Perspective on Language Knowledge and Use: Selected Papers from the 31st Linguistic Symposium on Romance Languages (LSRL), Chicago, 19-22 April 2001 (pp. 273-286). Amsterdam: John Benjamins Publishing Company.

de Villiers, J. G., \& Gxilishe, S. (2008). The acquisition of number agreement in English and Xhosa. Merging Features: Computation, Interpretation, and Acquisition (pp. 104123). Oxford University Press, Oxford, UK. doi.org/10.1093/acprof:oso/9780199553266.003.0006

Fenson, L., Dale, P. S., Reznick, J. S., Thal, D., Bates, E., Hartung, J. P., ... Reilly, J. S. (1993). The MacArthur communicative development inventories: User's guide and technical manual. Baltimore, MD: Paul H. Brookes. doi.org/10.1037/t11538-000

Gonzalez-Gomez, N., Hsin, L., Barrière, I., Nazzi, T., \& Legendre, G. (2017). Agarra, agarran: Evidence of early comprehension of subject-verb agreement in Spanish. Journal of Experimental Child Psychology, 160, 33-49. 


\section{SV COMPREHENSION \& PRODUCTION IN SPANISH}

doi:10.1016/j.jecp.2017.02.010

Grinstead, J. (2004). Subjects and Interface Delay in Child Spanish and Catalan. Language, 80(1), 40-72. doi.org/10.1353/lan.2004.0024

Gutiérrez-Bravo, R. (2013). Structural markedness and syntactic structure: A study of word order and the left periphery in Mexican Spanish. New York and London: Routledge. doi.org/10.4324/9780203959602

Gxilishe, S., Smouse, M., Xhalisa, T., \& De Villiers, J. (2009). Children's insensitivity to information from the target of agreement: the case of Xhosa. In Proceedings of the 3rd Conference on Generative Approaches to Language Acquisition North America (pp. 46-53).Cascadilla Press, Somerville, MA.

doi.org/10.1093/acprof:oso/9780199553266.003.0006

Hsieh, L., Leonard, L. B., \& Swanson, L. (1999). Some differences between English plural noun inflections and third singular verb inflections in the input: the contributions of frequency, sentence position, and duration. Journal of Child Language, 26(3), 531543. doi.org/10.1017/s030500099900392x

Hsin, L. (2014). Integrated bilingual grammatical architecture: Insights from syntactic development (Doctoral dissertation). Retrieved from https://jscholarship.library.jhu.edu/handle/1774.2/37142

Hsin, L., \& Legendre, G. (2019). Strong Integration in bilingual grammar, formalized: Making the case from cross-linguistic influence in wh-questions. Linguistic Approaches to Bilingualism, 9(3) 427-467.

Jackson-Maldonado, D., Thal, D., Marchman, V., Bates, E., \& Gutierrez-Clellen, V. (1993). Early lexical development in Spanish-speaking infants and toddlers. Journal of Child Language, 20(3), 523-549. doi.org/10.1017/s0305000900008461

Jakubowicz, C. and Rigaut C. (2000). L'acquisition des clitiques nominatifs et des clitiques 


\section{SV COMPREHENSION \& PRODUCTION IN SPANISH}

objets en français. Canadian Journal of Linguistics, 45 (1/2), 119-157.

Johnson, V. E., de Villiers, J. G., \& Seymour, H. N. (2005). Agreement without understanding? The case of third person singular/s/. First Language, 25(3), 317-330. doi.org/10.1177/0142723705053120

Kempchinsky, P. (2002). Locative Inversion, PP topicalization and the EPP. Amsterdam Studies in the Theory and History of Linguistic Science, 4, 145-159. doi.org/10.1075/cilt.220.11kem

Legendre, G., Barrière, I., Goyet, L., \& Nazzi, T. (2010). Comprehension of Infrequent Subject-Verb Agreement Forms: Evidence From French-Learning Children. Child Development, 81(6), 1859-1875. doi.org/10.1111/j.1467-8624.2010.01515.x

Legendre, G., Culbertson, J., Barrière, I., Nazzi T., and Goyet, L. (2010). Experimental and empirical evidence for the status and acquisition of subject clitics and agreement marking in adult and child Spoken French. In Torrens, V., Escobar, L., Gavarro, A., J. Gutierrez (Eds.) Movement and Clitics: Adult and Child Grammar. Newcastle: Cambridge Scholars Publishing. 333-360.

Legendre, G., Culbertson, J., Zaroukian, E., Hsin, L., Barrière, I., \& Nazzi, T. (2014). Is children's comprehension of subject-verb agreement universally late? Comparative evidence from French, English, and Spanish. Lingua, 144, 21-39. doi.org/10.1016/j.lingua.2013.05.004

Miller, K. (2012). Not all children agree: Acquisition of agreement when the input is variable. Language Learning and Development, 8, 255-277. https://doi.org/10.1080/15475441.2011.601249

Montrul, S. A. (2004). The acquisition of Spanish. Language Acquisition and Language Disorders. Amsterdam/Philadelphia: John Benjamins Publishing. doi.org/10.1075/lald.37 


\section{SV COMPREHENSION \& PRODUCTION IN SPANISH}

Nazzi, T., Barrière, I., Goyet, L., Kresh, S., \& Legendre, G. (2011). Tracking irregular morphophonological dependencies in natural language: Evidence from the acquisition of subject-verb agreement in French. Cognition, 120(1), 119-135. doi.org/10.1016/j.cognition.2011.03.004

Ordóñez, F., \& Treviño, E. (1999). Left dislocated subjects and the pro-drop parameter: A case study of Spanish. Lingua, 107(1), 39-68. doi.org/10.1016/s0024-3841(98)000205

Pérez-Leroux, A. T. (2005). Number problems in children. In Proceedings of the 2005 Canadian Linguistic Association Annual Conference (Vol. 12, p. 12). London, Canada: University of Western Ontario.

Seymour, H.N., Roeper, T., \& de Villiers, J.G. (2005). Diagnostic Evaluation of Language Variation: Norm Referenced (DELV-NR). The Psychological Corporation: San Antonio, TX.

Sundara, M., Demuth, K., \& Kuhl, P. K. (2011). Sentence-position effects on children's perception and production of English third person singular -s. Journal of Speech, Language, and Hearing Research, 54(1), 55-71. doi.org/10.1044/10924388(2010/10-0056)

Thordardottir, E. T. (2005). Early lexical and syntactic development in Quebec French and English: Implications for cross-linguistic and bilingual assessment. International Journal of Language \& Communication Disorders, 40(3), 243-278. https://doi.org/10.1080/13682820410001729655

Tomasello, M. (2003). Constructing a language: A usage-based approach to child language acquisition. Cambridge (MA).

Villa-García, J. (2011). Acquisitional evidence bearing on the account of preverbal and postverbal subjects in Spanish. In Selected proceedings of the 13th Hispanic 


\section{SV COMPREHENSION \& PRODUCTION IN SPANISH}

linguistics symposium (pp. 178-189). Somerville, Mass.: Cascadilla Press.

Wexler, K. (1998). Very early parameter setting and the unique checking constraint: A new explanation of the optional infinitive stage. Lingua, 106(1), 23-79. 


\section{SV COMPREHENSION \& PRODUCTION IN SPANISH}

\section{Appendices}

Appendix 1. Instructions and items presented from the Spanish DELV.

Ahora te voy a enseñar unas imágenes y te voy a decir algo sobre cada una. Quiero que mires las imágenes y que termines lo que voy a decir. Now I am going to show you some images and I will tell you something about each one. I want you to look at the images and complete what I tell you.

1. Veo unos papalotes pequeños y veo un papalote grande. Los niños tienen papalotes pequeños y la niña... I see small butterflies and I see a large butterfly. The boys have small butterflies and the girl...

2. Veo unas colas cortas y veo una cola larga. El gato tiene cola corta, pero los perros... I see some long tails and I see a short tail. The cat has a short tail, but the $\operatorname{dogs} \ldots$

3. Veo unas colchonetas y veo una cama. La niña siempre descansa en una cama y los niños... I see some mattresses and I see a bed. The girl always rests on a bed and the boys...

4. Veo unos caballos y veo una bicicleta. Las niñas siempre andan en bicicleta y el niño... I see some horses and I see a bicycle. The girls always ride on bicycles and the boy...

5. Veo unos platos y veo unos vasos. La niña siempre lava vasos y los niños... I see some plates and I see some glasses. The girl always washes glasses and the boys...

6. Veo un carrito y veo una carreola. Las niñas siempre empujan el carrito y la mamá siempre... I see a buggy and I see a stroller. The girls always push the buggy and the 


\section{SV COMPREHENSION \& PRODUCTION IN SPANISH}

boys...

7. La niña nada y el niño... The girl swims and the boy...

8. El niño juega basketball pero la niña... The boy plays basketball but the girl...

9. Veo un conejo y veo unos caballos. El conejo come zanahorias y los caballos... I see a rabbit and I see some horses. The rabbit eats carrots and the horses...

10. Estas niñas no podían levantarse de la cama y su mamá les dio medicina. Hoy ya no están enfermos. Por qué les dio su mama medicina ayer? These girls couldn't get out of bed and their mom gave them medicine. Today they are not sick. Why did their mom give them medicine yesterday?

Appendix 2. Sample items from the comprehension task. Sentence-medial items presented with singular agreement morphology; sentence-final items presented with plural agreement morphology. Medial and final items separated by a forward slash.

1. Saltan en la banca. They jump on the bench. / En la banca saltan. On the bench (they) jump.

2. Corren en la calle. (They) run in the street. / En la calle corren. In the street (they) run.

3. Lloran en el jardín. (They) cry in the garden. / En el jardin lloran. In the garden (they) cry.

4. Comen en la cocina. (They) eat in the kitchen. / En la cocina comen. In the kitchen (they) eat.

5. Escriben en la mesa. (They) write on the table. / En la mesa escriben. On the table (they) write. 


\section{SV COMPREHENSION \& PRODUCTION IN SPANISH}

6. Dibujan en al pizarrón. (They) draw on the chalkboard. / En el pizarrón dibujan. On the chalkboard (they) draw.

7. Leen en el sillón. (They) read on the sofa. / En el sillón leen. On the sofa (they) read.

8. Juegan en el parque. (They) play in the park. / En el parque juegan. In the park (they) play. 